\title{
The Common Frame of Reference (CFR) of European Insurance Contract Law
}

\section{Helmut Heiss}

Published online: 23 August 2008

(C) ERA 2008

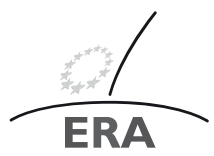

EUROPÄISCHE RECHTSAKADEMIE ACADEMY OF EUROPEAN LAW ACADEMIE DE DROIT EUROPEEN ACADEME DE DROT EUROPEEN TRIER - TREVES - TREVIRI

\section{The Common Frame of Reference Project}

\subsection{The Project and its Purposes}

In its Action Plan of 12 February 2003 (the "Communication from the Commission to the European Parliament and the Council - A more coherent European contract law - An action plan") ${ }^{1}$ and its Communication on "European Contract Law and the Revision of the Acquis: The Way Forward" of 11 October 2004², the European Commission announced the establishment of a Common Frame of Reference of European Contract Law. According to the Commission's Action Plan of 12 February 2003, the CFR shall comprise Definitions and Rules and both shall be accompanied by Comments and Notes. The Comments will contain explanations and illustrations of the proposed Rules. The Notes will give reference to the status quo of contract law in the Member States as well as the existing acquis communautaire.

The CFR will be drafted in order to establish a set of rules which provide the definitions, structure and contents of European contract law developed through a comparative legal analysis of national contract laws. ${ }^{3}$ Strictly speaking, these

\footnotetext{
Prof. Dr. jur. Helmut Heiss $(\bowtie)$

University of Zürich, Chair for Private Law and Comparative Law

Treichlerstrasse 10, 8032 Zürich, Switzerland

e-mail: helmut.heiss@rwi.unizh.ch
}

This article is based on the opening speech given by the author at the seminar European Insurance Contract Law and the Common Frame of Reference, organised by ERA in cooperation with the Joint Network on European Private Law, held in Trier on 21-22 January 2008, and on previous publications such as Heiss [14]; Clarke/Heiss [10]; Heiss [16].

1) COM (2003) 68 final; in more detail Schulze [33].

2) COM (2004) 651 final.

3) COM (2004) 651 final, para. 2.2.1 and 3.1.; see also Schulze [33], p. 135. 
definitions and principles will not be of a binding nature since they will not be enacted as a regulation or directive. ${ }^{4}$ The Commission is, however, clearly determined to adhere to the terminology and system of the CFR in any later legislation concerning contracts. ${ }^{5}$ Furthermore, the CFR may become an important aid for the European Court of Justice in procedures for preliminary rulings ${ }^{6}$ and also for national courts with regard to autonomous interpretations of the existing acquis communautaire. Not least, international academic discussion in Europe could be based on the common rules provided by the CFR. This instrument would, to some extent, provide Europe with a common legal language, as was the case with Latin until national codifications replaced the ius commune. It would allow law faculties to teach contract law with a European and comparative perspective. National legislators could also contribute to harmonisation by adopting the rules of the CFR in future reforms of national contract law. This applies in particular to the former socialist countries, which are revising their contract law. ${ }^{7}$ Ultimately, one may regard the CFR as a European lex mercatoria ${ }^{8}$ and as such it may be applied in arbitration proceedings. ${ }^{9}$

\subsection{The Role of the „CoPECL Network“}

Following an initiative by the European Commission, the "CoPECL Network of Excellence" was founded in May 2005. The Network is drafting a proposal for the "Common Frame of Reference" (CFR) of European contract law as proposed by the European Commission. ${ }^{10} \mathrm{~A}$ first draft of the CFR was presented to the European Commission at the end of 2007. ${ }^{11}$ The final draft is expected by the end of 2008 .

The CoPECL Network comprises universities, institutions and other organisations with more than 150 researchers operating in all of the EU Member States. The following groups participate in the Network: The Study Group on a European Civil Code; The Research Group on the Existing EC Private Law, or "Acquis Group"; The Project Group on a Restatement of European Insurance Contract Law, or "Insurance Group"; The Association Henri Capitant together with the Société de Législation Comparée and the Conseil Supérieur du Notariat; The Common Core Group; The Research Group on the Economic Assessment of Contract Law Rules, or "Econom-

4) COM (2004) 651 final, para. 2.1.3.

5) $\mathrm{COM}(2004) 651$ final, para. 2.1.2.

6) Trstenjak [35]; the PECL and the draft CFR have recently been cited by Advocate-General M. Poiares Maduro in his opinion of 21 November 2007 on Case C-412/06 (Annelore Hamilton v. Volksbank Filder eG) in support of his interpretation of the third paragraph of Art. 4 of the Doorstep Selling Directive.

7) With a view to insurance contract law, see also the opinion of the EESC, CESE 1626/2004, para. 4.3.1.; as to the overall topic, Heiss [18]; concerning the transformation of the market, see Münchener Rück [26]; Bayerische Rück [6].

8) See Blaurock [7].

9) See also Art. 1:101 PECL (Application of the Principles):

“...(3) These Principles may be applied when the parties:

(a) have agreed that their contract is to be governed by "general principles of law", the "lex mercatoria" or the like; ...".

${ }^{10)}$ In this process, the Network is involved in an ongoing dialogue with so called "stakeholders"; as to their role and views, see Brödermann [8].

${ }^{11)}$ See www.copecl.org; the draft on insurance contracts has been published at www.restatement.info. 
ic Impact Group" (TILEC - Tilburg Law and Economics Center); The "Database Group"; and The Academy of European Law (ERA). ${ }^{12}$

\section{Insurance Contract Law within the CFR}

Insurance contract law plays an important role in the 2003 Action Plan of the European Commission. The Plan repeatedly refers to the necessity of harmonising the law on insurance contracts. The Commission argues that "firms are unable to offer, or are deterred from offering, financial services across borders, because products are designed in accordance with local legal requirements"13 and points out that "the same problems occur particularly with insurance contracts". ${ }^{14}$

The European Commission's position is supported by an (own-initiative) Opinion of the European Economic and Social Committee (EESC) on the topic "The European Insurance Contract" which was delivered on 15 December 2004. ${ }^{15}$ In this Opinion, the EESC considered the shortcomings of the existing internal insurance market. It confirmed the view that some kind of a European insurance contract law must be at hand in order to allow a cross border provision of insurance services. Therefore, the EESC encouraged the Commission to take steps towards unifying insurance contract law in the EU. The endeavour to establish a Common Frame of Reference of European Contract Law, which includes special rules on insurance, is at least the first attempt of the European Commission to comply with the request of the EESC.

The European Commission's Action Plan and the Opinion of the EESC are both supported by the results of academic research work, which confirm the need for a European insurance contract law for the functioning of the internal market in the insurance sector. As highlighted by Fritz Reichert-Facilides, an attempt by the European legislator to make the internal market work solely by harmonising the conflict of law rules for insurance contracts has failed. ${ }^{16}$ An analysis by Jürgen Basedow shows that harmonisation of private international law applied to insurance contracts was in fact an inadequate method of creating an internal insurance market. ${ }^{17}$ For the sake of policyholder protection, which is held to be a "general good" by the ECJ ${ }^{18}$, the pertinent rules of private international law are, to a large extent, mandatory. According to Art. 9(1)(b) of the Brussels I Regulation, a policyholder, insured or beneficiary may bring an action against an insurer at the court where the plaintiff is domiciled. In accordance with the pertinent rules of private international law as laid down in the directives ${ }^{19}$, the law applicable to the insurance contract will often be the law of the state in which the policyholder has his habitual residence. It follows that litigation in matters relating to (mass risk) insurance will usually take place in the policyholder's

\footnotetext{
${ }^{12)}$ Further information is provided by the CoPECL Network at www.copecl.org.

13) COM (2003) 68 final, para. 47.

14) COM (2003) 68 final, para. 48.

15) CESE 1626/2004; with regard to this Opinion, Heiss [13].

16) Reichert-Facilides [29]; Reichert-Facilides [28].

17) Basedow [3].

${ }^{18)}$ ECJ 4 December 1986 Rec 1986, 3755 (Commission ./. FRG).

19) As to the law in the directives, Wandt [36].
} 
home country and be subjected to the law of this country as well. ${ }^{20}$ Consequently, insurers must be, and actually are, aware of the fact that any product they sell crossborder will be subjected to laws different to those in their home country. Insurers must, therefore, adapt their products to the legal environment, especially to the mandatory rules of (insurance) contract law, in which they sell them.

The impact of foreign mandatory rules on an insurance product can be severe. ${ }^{21}$ If, for example, an insurance product which is lawfully marketed in England is sold cross-border to a German customer, German courts might subject the contract terms of the English insurer to a control under $\S \S 305$ et seq BGB. A particular exception contained in the contract terms, which is exempt from control under the English Unfair Terms in Consumer Contracts Regulation 1999 in principle ${ }^{22}$, may be subject to control under German law and could be held to be invalid according to $\S 307$ BGB. If so, the scope of cover of one and the same particular insurance product will be broader in Germany than in England due to the differences in the applicable (mandatory) law. Insurers will, thus, be reluctant to provide cross-border services. ${ }^{23}$

In fact, statistics show that cross-border provision of insurance services plays a minor role in the internal European market at least with regard to insurances of mass risks ${ }^{24}$, a fact which has been repeatedly acknowledged by the European Commission. ${ }^{25}$ Insurers perform their international business predominantly through subsidiaries or daughter companies. Even though such international activities are widely observed in the EU, they are insufficient to establish an internal market for insurance products. The products sold by foreign subsidiaries or daughter companies are not identical to those sold by the insurer in the country in which it is domiciled. Products in the country of the subsidiary or daughter company are either developed completely independently from the products sold on the insurer's home market or at least adapted to the legal regime of the state where the insurance product is sold. Consequently, customers do not have access to foreign insurance products.

Summing up this analysis, a (clearly simplified) result could be stated: There are insurance companies which sell insurance products abroad through subsidiaries or daughter companies. However, foreign (mass) insurance products are not sold abroad in the same form as at the place of origin and the competition between creative insurance solutions throughout Europe remains rather restricted as a result. Insurance enterprises are not in a position to compete with their innovative products throughout Europe, and customers are also not in a position to access fully various national insurance solutions. The internal market of insurance products has, as such, not been completed.

It may be argued that the shortcomings of the internal insurance market in its current state could be overcome by a shift in European international insurance contract law which would allow parties to choose the law of the insurer's home country as the

\footnotetext{
20) See e.g. Heiss [17], p. 8 et seq.

${ }^{21)}$ Basedow [5]; for further obstacles deriving from the nature of insurance contracts see Comité Européen des Assurances, CEA Policy Report on 'The European Retail Insurance Market(s)' (2004), http://www. cea.assur.org/cea/download/publ/article192.pdf.

${ }^{22)}$ For details, see Clarke [9], p. 590 et seq.

23) For further examples, see Heiss [15].

24) See Basedow [3], p. 17 referring to data provided by EUROSTAT.

25) See supra 2.
} 
law applicable to the insurance contract. However, this argument is flawed. First of all, the approach would deprive the policyholder of his private international legal protection which does not appear to be acceptable as a matter of legal policy. Secondly, the mentioned shift in the rules of private international law would lead to a switch over in the behaviour of insurers and policyholders. Whereas, under the current regime of private international law, it is the insurer who hesitates to provide cross border services, the policyholder would be reluctant to acquire foreign insurance products under a reversed regime of private international law because he would object to the application of foreign law. The internal market would remain incomplete. ${ }^{26}$

Insurance contract law is, hence, one of the predominant areas of contract law in which a European codification is necessary to overcome the existing barriers to the internal market. The European Commission reflected this necessity in its 2004 Communication where, with regard to the structure of a Common Frame of Reference, it stated: "[ [... two types of contracts which were mentioned specifically were consumer and insurance contracts. The Commission expects the preparation of the CFR to pay specific attention to these two areas." 27 This predominant position of the insurance contract within the CFR is also reflected in the tentative proposal provided by the European Commission in its Appendix I ("Possible structure of the CFR") to the 2004 Communication. Accordingly, insurance contract forms a part of Chapter II, Section IX of the Common Frame of Reference and - alongside sales contracts - is the only type of contract, which will be treated specifically.

\section{The CFR of European Insurance Contract Law}

\subsection{Responsibility of the "Insurance Group"}

Within the CoPECL Network, the Project Group for "Restatement of European Insurance Contract Law" (the "Insurance Group"), which was founded by the late Professor Fritz Reichert-Facilides in 1999, is in charge of drafting the CFR of insurance contract law. In fact, the Project Group has been drafting the Principles of European Insurance Contract Law (PEICL) since its establishment in 1999. The PEICL have been drafted as Rules, followed by Comments which provide the reasons for the Rules and illustrate their proper application by giving examples, as well as Notes which reproduce the status quo of insurance contract law in the Member States and in the acquis communautaire. The Group completed drafting the Principles (except the Rules on specific branches of insurance) in a workshop held in Paris in September 2007 and the Drafting Committee of the Group, headed by Malcolm Clarke, finished revising the text at its meeting in Innsbruck in December 2007. The finalised PEICL were submitted to the European Commission as a Draft CFR of European Insurance Contract Law on 17 December 2007.

The work of the Project Group will of course go beyond this point. As of 2008, it will start drafting special rules for individual branches of insurance, beginning with life assurance (including collective agreements) and liability insurance.

\footnotetext{
26) For more detail, see Basedow [3], p. 20 et seq.; Heiss [17], p. 13 et seq.

27) COM (2004) 651 final, para. 3.1.3.
} 


\subsection{The Approach}

\subsubsection{Scope of Application}

The Insurance Group primarily provides general rules of insurance contract law. The substantive scope of application of the PEICL, therefore, encompasses all types of insurance except reinsurance. ${ }^{28}$ Insurances of special risks (e. g. marine and aviation insurance) as well as large risks are covered by the PEICL, notwithstanding the fact that the second sentence of Art. 1:103(2) of the PEICL grants parties freedom of contract in those cases.

\subsubsection{Matters not Regulated in the PEICL}

In spite of their broad scope of application, the PEICL do not govern every aspect which may become relevant in matters concerning insurance contracts. On the contrary, they abstain, in principle, from regulating issues of general contract law. The resulting gap must be filled in a way that takes as little recourse to national law as possible. Consequently, the first sentence of Art. 1:105(1) of the PEICL prohibits any recourse to national law when applying the PEICL. Instead, Art. 1:105(2) provides for an application of the Principles of European Contract Law (PECL), drafted by the so-called Lando-Commission, in the most recent edition. ${ }^{29}$ By this reference, the PECL become the lex generalis to the PEICL. Furthermore, the Project Group has consistently drafted the PEICL with a view towards the PECL, not only as far as terminology is concerned but also in order to avoid duplications in the regulations. Whenever a rule of the PECL also appeared to be appropriate in the context of insurance, the Project Group abstained from regulating the matter in the PEICL. Nevertheless, some provisions were more or less "copied" from the PECL into the PEICL for a rather simple reason: The provisions of the PECL are, in principle, not mandatory. However, the Project Group thought that some of these non-mandatory provisions should be mandatory in the context of insurance. This goal was to be reached by copying these provisions into the PEICL and thereby making them mandatory according to the first sentence of Art. 1:103(2) of the PEICL.

Whenever an issue is neither regulated in the PEICL nor in the PECL, Art. 1:105(2) of the PEICL refers to the principles common to the laws of the Member States. Art. 1:105(2) of the PEICL clearly prescribes the judge to use methods of comparative law to fill gaps.

It has been mentioned that the PEICL do not (yet) govern individual branches of insurance. However, some types of insurance contracts, such as life or health insurance, are strongly regulated by mandatory provisions in national laws. It, therefore, seems inconceivable to apply the PEICL to such branches without recourse to the (otherwise applicable) national provisions of law as otherwise the protection of the policyholder would be undermined. Hence, the second sentence of Art. 1:105(1) of the PEICL provides for the application of the mandatory rules in the applicable national law which regulate special types of insurance contracts. This application of national law is, how-

\footnotetext{
28) See Art. 1:101 of the PEICL.

${ }^{29)}$ Lando/Beale [22]; Lando/Clive/Prüm/Zimmermann [23].
} 
ever, limited to the period of time in which the PEICL do not provide for special branch rules themselves. In this context, it is worth mentioning again that the Project Group will start drafting rules on life assurance and liability insurance in 2008.

\subsubsection{Mandatory Rules}

As indicated earlier, it is the mandatory rules of national insurance contract law which form a barrier to the proper functioning of the internal insurance market. For this reason, the Insurance Group restricts its work to drafting of European principles which are mandatory and therefore capable of substituting national mandatory law.

The mandatory character of the Rules can be twofold. On the one hand, there are Rules which must not be derogated from by parties' agreement at all. Such "absolutely" mandatory rules are mentioned in Art. 1:103(1) of the PEICL which reads: "Articles ... are mandatory." Art. 1:103(1) of the PEICL was drafted as a framework provision which would be filled with references to specific provisions that should be absolutely mandatory in the course of the drafting of the PEICL. However, up until today, none of the provisions of the PEICL have been made absolutely mandatory by the Project Group and Art. 1:103 remains an empty framework provision for the time being.

The mandatory character of the PEICL is thus far of a different kind and may be described as "semi-mandatory". The first sentence of Art. 1:103(2) of the PEICL states: "The contract may derogate from all other provisions of the PEICL as long as such derogation is not to the detriment of the policyholder, the insured or beneficiary."

As has already been mentioned, the mandatory character of the PEICL is limited to mass risk insurance. Since mandatory rules of insurance law purport the protection of the policyholder as the weaker party, the mandatory character must be abolished when there is no need for protection, as is the case with special and large risk insurances. Mass risks are differentiated from special or large risks by a statutory definition which is in line with the existing acquis communautaire, in particular in the field of international procedural law ("Brussels I"30) as well as conflict of laws (currently contained in the EC directives on insurance law ${ }^{31}$ which will be substituted by the "Rome I" Regulation ${ }^{32}$ upon its entry into force). This definition of special and large risks is adopted by the second sentence of Art. 1:103(2) of the PEICL. The protection granted to the policyholder under the PEICL is consequently not restricted to consumer contracts but applies to all mass risks including insurance contracts concluded by small or medium-sized enterprises.

\subsubsection{The PEICL and the Existing Acquis Communautaire}

It has been mentioned that the definition of special and large risks in the second sentence of Art. 1:103(2) of the PEICL follows the sample found in the existing insurance acquis. This shows that the Group endeavours to adhere to the existing

\footnotetext{
${ }^{30)}$ See Art. 13(5) Brussels I referring to the relevant definitions in the directives.

${ }^{31)}$ The definition of large risks is given by Art. 5 of the First Non-Life Directive (Directive 73/239/EEC as amended).

${ }^{32)}$ Regulation (EC) No 593/2008 of the European Parliament and of the Council of 17 June 2008 on the law applicable to contractual obligations (Rome I).
} 
acquis communautaire as closely as possible unless shortcomings indicate the appropriateness of a deviation. In addition to the insurance acquis, several directives on consumer contract law ${ }^{33}$ outlining the information duties of the entrepreneur and withdrawal rights of the consumer ${ }^{34}$, a control of unfair contract terms ${ }^{35}$ as well as injunctions ${ }^{36}$ were implemented by the PEICL. The PEICL also transpose the Directive on non-discrimination which contains a special provision for insurance contracts. ${ }^{37}$

The PEICL do not transpose the Directive on insurance intermediaries ${ }^{38}$ as they do not deal with professional duties of intermediaries at all. ${ }^{39}$ However, the Directive has been considered and has given the Group some inspiration for regulating precontractual information and advice duties of the insurer.

\subsubsection{Language and Terminology}

The PEICL have been drafted in English and while they are currently available in various other languages, English will remain the language in which the Insurance Group advances its work. English terminology is accordingly used for the PEICL. However, this does not necessarily mean that the Group has used national English legal terminology. Quite the contrary, in order to avoid the impression that a particular provision merely codifies a concept of English common law, the Group has departed from English legal terminology on many occasions. For example, the PEICL do not refer to "promissory warranties" but to "precautionary measures" 40 in order to avoid giving the wrong impression that the PEICL have implemented the English concept of "warranties". At the same time, the Insurance Group has attempted to use as much international legal terminology as was available. First of all, the Group adhered as far as possible to the terminology of the PECL as well as the existing acquis communautaire. Secondly, it had recourse to terminology found in international transport conventions, e.g. to the phrase "with intent to cause the loss or recklessly and with knowledge that the loss would probably result", which is used on several occasions throughout the PEICL.

\subsubsection{Uniform Interpretation and Application}

The effectiveness of a European insurance contract law cannot be guaranteed by the uniform text of the PEICL itself but instead depends to a large degree on its uniform

\footnotetext{
${ }^{33)}$ Regarding to the relevance of the consumer acquis in the field of insurance, see Heiss/Schnyder [20].

${ }^{34)}$ See in particular Directive 2002/65/EC of the European Parliament and of the Council of 23 September 2002 concerning the distance marketing of consumer financial services and amending Council Directive 90/619/EEC and Directives 97/7/EC and 98/27/EC (OJ 2002 L 271/16).

${ }^{35)}$ See Council Directive 93/13/EEC of 5 April 1993 on unfair terms in consumer contracts (OJ 1993 L 95/29).

36) See Directive 98/27/EC of the European Parliament and of the Council of 19 May 1998 on injunctions for the protection of consumers' interests, OJ 1998 No L 166/51.

${ }^{37)}$ See Art. 5 of the Council Directive 2004/113/EC of 13 December 2004 implementing the principle of equal treatment between men and women in the access to and supply of goods and services, OJ 2004 No L 373/37; equal treatment is regulated in Art. 1:207 of the PEICL.

${ }^{38)}$ Directive 2002/92/EC of the European Parliament and of the Council of 9 December 2002 on insurance mediation, OJ 2003 No L 9/3.

${ }^{39)}$ With regard to the reason for not regulating the professional duties of the intermediaries see infra 3.2.8.

${ }^{40)}$ See the heading of Section One of Chapter Four of the PEICL.
} 
application by national courts. Art. 1:104 of the PEICL, therefore, states general criteria by which the PEICL should be interpreted. Among these criteria, the "uniformity of application" plays a significant role. ${ }^{41}$ In spite of this rule on interpretation, it would clearly be desirable, for the sake of uniform application of the PEICL, for the ECJ to give preliminary rulings on the interpretation of the PEICL. Following Art. 234 EC this would, however, require the European legislator to enact the PEICL as (secondary) EC law.

\subsubsection{Enforcement}

In principle, the policyholder, insured and beneficiary have to enforce their rights by bringing an action in court. The PEICL themselves do not provide for an out-of-court complaint and redress mechanism. They also, however, do not interfere with existing mechanisms of alternative dispute resolution, such as ombudsmen bureaus. In fact, the insurer is under a duty to inform the policyholder about such mechanisms according to Art. 2:201(1)(k) and Art. 2:501(k) of the PEICL.

Moreover, the PEICL allow qualified entities to seize a competent national court or authority and seek an order prohibiting or requiring the cessation of infringements of the PEICL. ${ }^{42}$ The "qualified entity" is defined by reference to the list drawn up by the European Commission in pursuance of Art. 4 of the Directive 98/27/EC of the European Parliament and of the Council of 19 May 1998 on injunctions for the protection of consumers' interests. ${ }^{43}$

\subsubsection{Optionality}

The PEICL have been drafted as an optional instrument. Thus, they are only to be applied if they are chosen by the parties to the contract. The pertinent Art. 1:102 of the PEICL reads as follows:

Article 1:102:

Optional Application

The PEICL shall apply when the parties, notwithstanding any limitations of choice of law rules under private international law, have agreed that their contract shall be governed by it. In that event, subject to Article 1:103, the parties shall apply the PEICL as a whole and shall not exclude the application of particular provisions.

The main function of this rule is to provide a choice which will be unrestricted by the applicable rules of private international law in the Rome Convention and in the directives on insurance law, as well as the forthcoming rules in the "Rome I" Regulation. The choice is granted for international as well as purely national contracts. At the same time, the second sentence of Art. 1:102 of the PEICL rules out a partial

\footnotetext{
41) A similar rule can be found in Art. 7 CISG.

42) Art. 1:301(1) of the PEICL.

${ }^{43)}$ See Art. 1:301(2) of the PEICL referring to the Directive 98/27/EC of the European Parliament and of the Council of 19 May 1998 on injunctions for the protection of consumers' interests, OJ 1998 No L 166/51; Art. 1:301 of the PEICL is the only provision of the PEICL which only applies to insurance contracts taken out by consumers.
} 
choice of the PEICL. Parties may, thus, only opt for an application of all or none of the PEICL but no "law mix" is allowed.

The optional character of the PEICL is also of influence on their contents. Since the option is given to the parties of the insurance contract, i. e. the insurer and the policyholder, its effects must be restricted to the parties themselves but include the beneficiary and the insured because their rights depend on the parties' agreement. Third parties must, however, not be adversely affected by the parties' choice. This applies, inter alia, to intermediaries who are not parties to the insurance contract. The legal position of intermediaries will not be affected by the parties' choice in favour of the PEICL. Hence, the PEICL do not regulate the duties of the insurance intermediaries, rather only the liability of the insurer for its agents and apparent brokers. ${ }^{44}$

\subsection{Practical Impact of the CFR of European (Insurance) Contract Law}

The CFR could considerably boost the development of European contract law in general and insurance contract law in particular. It will, first and foremost, be a helpful tool for the interpretation as well as a revision of the existing consumer acquis. However, in spite of these advancements, the CFR will, in itself, not be sufficient to complete the internal insurance market. ${ }^{45}$ Since it will only provide non-binding rules, the CFR will not be available to the parties as the choice for the applicable insurance law and insurance contracts will still be subjected to national law. The obstacles to the functioning of the internal insurance market presented by the diversity of national mandatory insurance contract law will not be removed and cross-border sales will remain an exception. For this reason, it has been argued that a functioning internal insurance market will require more, i. e. an optional instrument of European insurance contract law. ${ }^{46}$

\section{The PEICL as a Future Optional Instrument of European Insurance Contract Law?}

\subsection{What is an Optional Instrument?}

An optional instrument of European contract law is characterised by the fact that its application depends on a choice by the parties to the contract. ${ }^{47}$ Therefore, it would not replace national contract law but would instead provide the parties with an alternative. ${ }^{48}$ This is why a possible future optional instrument has been called the 28th regime of contract law in Europe. ${ }^{49}$ In general terms, it may be compared to the UN

\footnotetext{
44) See Arts. 3:101 and 3:102 of the PEICL.

45) See Basedow [1], p. 283.

46) See Basedow [1], p. 285; concerning the relationship of the CFR to a possible future optional instrument, see Flessner [11].

47) Heiss/Downes [19], p. 695; Clarke/Heiss [10], p. 605; some authors also mention a choice of the member state, see e.g. Grundmann/Kerber [12], p. 310; this alternative will not be discussed in this article; as to yet another way of understanding 'optional', see Lando [21].

48) Heiss/Downes [19], p. 695; see Staudenmayer [34], p. 832.

49) On the optional European Contract Law in general, Staudenmayer [34]; regarding insurance contract law, Basedow [2], p. 100 et seq.
} 
Convention on Contracts for the International Sale of Goods (CISG) which, in its Art. 6, allows parties to opt out, i. e. to agree that the Convention will not apply to their contract. ${ }^{50}$ However, in a European optional instrument, it is quite likely that an opt-in approach will be used by the European legislator as opposed to the opt-out approach in Art. 6 CISG. ${ }^{51}$

\subsection{Advantages of an Optional Instrument}

An optional instrument would allow parties to conclude their contract on the basis of European law instead of national law. This option would offer advantages particularly to "multiple players", such as entrepreneurs doing business in the European internal market, who would not have to be concerned with the impact of diverging national contract law regimes on their transactions. The costs of legal research and adaptation of the contract to each national system of contract law would disappear. Overall, a European optional instrument would facilitate transactions.

However, the aforementioned advantages are not specific to an optional instrument. They could also be achieved by a non-optional European contract law replacing national systems. The predominant reasons in favour of an optional instrument are to be found elsewhere. First of all, an optional instrument has far better chances of finding political approval than a non-optional instrument. National legislators, encouraged by national representatives of the legal profession, would be more inclined to resist an instrument which replaced national contract law. They would, however, have no reason to resent a 28 th regime of contract law that left national law untouched. ${ }^{52}$ Secondly, an optional instrument appears to be economically more efficient because it does not force parties to alter their traditional ways of doing business but merely provides them with an additional option. Entrepreneurs acting internationally will be more inclined to take the chance than others acting only locally. In other words, there is no need to submit everyday contracts, such as the sale of bread concluded between the owner of a bakery in London and his neighbour, to the rules of European contract law. Replacing the English common law of contract would only impose costs on the baker as well as his customer, since they would be forced to adapt their way of contracting with each other to new European rules without any advantage. On the other hand, the producer of electronic devices who sells cross-border has a substantial interest in concluding every contract on the basis of one and the same (i. e. European) set of rules of contract law, regardless of whether he sells to an English, German or French customer.

\subsection{The Option}

\subsubsection{Choice of General Principles of European Contract Law by the Parties?}

It has been held that under the current European regime of international contract law Art. 3 of the Rome Convention -, the parties may not only choose the law of a country

\footnotetext{
50) Schlechtriem [31], p. 15 et seq.

51) Basedow [4].

${ }^{52)}$ Heiss [17], p. 36; with regard to the aspect of competition between legal orders, see Heiss/Downes [19], p. 693 (696 and fn. 11).
} 
but also "General Principles of Contract Law", such as the Lando Principles (PECL) or the UNIDROIT Principles as the law applicable to the contract. ${ }^{53}$ This means that through a choice made by the parties, non-binding rules would become the law applicable to a contract, thereby replacing the national legal regime which would have been applicable in the absence of a choice. This view is, of course, still heavily disputed in legal literature ${ }^{54}$ and it has not been confirmed by any court decision so far. Furthermore, the question has been left in an uncertain state by the new "Rome I" Regulation. Recital 13 of the Regulation does not positively confirm the possibility of a choice of non-binding rules. It only negatively specifies that the "Rome I" Regulation does not preclude any incorporation of a "non-State body of law" by choice of the parties. Recital 13 may be read as an encouragement for judges to accept a choice of general principles of contract law by the parties but does not guarantee such a choice.

In any case a choice of non-binding rules implies structural deficiencies, partly frustrating the purposes of an optional instrument. ${ }^{55}$ This would occur mainly because a choice of law under Art. 3 of the Rome Convention/"Rome I" Regulation would be subjected to several exclusions and restrictions. In purely domestic cases, there must be no derogation from national mandatory rules. ${ }^{56}$ The choice of the parties in consumer $^{57}$ and labour contracts ${ }^{58}$ would be restricted and national courts would be allowed to enforce internationally mandatory laws, even if the optional instrument were chosen. ${ }^{59}$ National law would consequently still have a high impact on contracts concluded in the Community. ${ }^{60}$

\subsubsection{EC Regulation}

Another way to provide the parties with a choice of the PECL and/or PEICL as optional instruments would be to enact them as EC regulations making them immediately applicable in every Member State. ${ }^{61}$ As a result, the PECL and the PEICL would not represent a $28^{\text {th }}$ regime of (insurance) contract law in Europe but a $2^{\text {nd }}$ regime of (insurance) contract law in each Member State. ${ }^{62}$ At the same time, the EC regulations could grant an option to the parties, by way of a unilateral conflict rule, allowing them to replace the applicable national (insurance) contract law with the PECL and/ or the PEICL. This approach is the preferable solution because it avoids the structural deficiencies mentioned in the context of Art. 3 of the Rome Convention/"Rome I" Regulation. Indeed, Recital 14 of "Rome I" Regulation specifically mentions the possibility of enacting such an optional instrument in the future. Recital 14 may be read as an announcement of future legislative activities, yet it does not guarantee that an optional instrument will be adopted.

\footnotetext{
53) With regard to the pertinent discussion, see Martiny [25], p. 217; Reithmann/Martiny [30], Art. 27 EGBGB no 12 .

54) See also Martiny [25], p. 217.

${ }^{55)}$ Heiss/Downes [19], p. 701 et seq.

56) Art. 3(3) of the Rome Convention/Arts. 3(3) and (4) of the "Rome I" Regulation.

57) Art. 5 of the Rome Convention/Art. 6 of the "Rome I" Regulation.

${ }^{58)}$ Art. 6 of the Rome Convention/Art. 8 of the "Rome I" Regulation.

${ }^{59)}$ Art. 7 of the Rome Convention/Art. 9 of the "Rome I" Regulation.

${ }^{60)}$ See also Schnyder [32], p. 66 et seq. favouring a greater freedom of choice.

${ }^{61)}$ Basedow [2], p. 109; Clarke/Heiss [10], p. 605 et seq.

62) See Heiss [17], p. 38.
} 


\subsection{The Optional Instrument and European Insurance Contract Law}

\subsubsection{Option Must also be Available for Purely Domestic Contracts}

The facilitation of insurance transactions in the single European market will only take full effect if all the contracts of a particular insurer may be subjected to the optional instrument. Parties must, therefore, also be given that option for purely domestic contracts, i.e. insurance contracts between policyholders and insurers with their seat or habitual place of residence in the same Member State and concerning a risk also situated in this Member State. ${ }^{63}$ Otherwise, domestic insurance contracts, which usually represent the biggest share of an insurer's business, would have to be designed and calculated according to national law and only cross-border insurance services could be subjected to the optional instrument. As a consequence, the pooling of risks would be more burdensome and many insurers would probably not enter into cross border transactions. For this reason, as far as insurance is concerned, restrictions on the scope of application of an optional instrument for European contract law to crossborder transactions, as proposed by some authors, must be rejected. ${ }^{64}$

\subsubsection{Comprehensive Instead of Minimum Standard Regulation}

Insurance law is similar to consumer law in that it protects the weaker party. ${ }^{65}$ Several EC directives have been enacted in the field of consumer contract law and most of them contain so-called minimum standard clauses which allow national legislators to provide consumers with a higher standard of protection than required, as long as such national rules do not violate the fundamental economic freedoms of the EC Treaty. ${ }^{66}$ It is worth mentioning that in the Directive concerning the distance selling of financial services to consumers, the EC did not enact a general minimum standard clause, which may indicate a shift in community legal policy. ${ }^{67} \mathrm{Be}$ that as it may, in the case of an optional instrument in the insurance sector, a minimum standard clause would seriously jeopardise its fundamental purpose, i. e. to allow the insurer to sell and the policyholder to buy insurance anywhere in Europe and based solely on one legal regime. This objective would be frustrated if national legislators could impose higher levels of policyholder protection. ${ }^{68}$ The optional instrument must regulate the

\footnotetext{
${ }^{63)}$ Heiss/Downes [19], p. 702 et seq; see also Martiny [25], p. 221.

${ }^{64)}$ See Basedow [2], p. 108 et seq.

${ }^{65)}$ Reichert-Facilides [29], p. 6 et seq.

${ }^{66)}$ See Art. 8 of the Council Directive 93/13/EEC of 5 April 1993 on unfair terms in consumer contracts (OJ 1993 L 95/29); Art. 11 of the Directive 94/47/EC of the European Parliament and the Council of 26 October 1994 on the protection of purchasers in respect of certain aspects of contracts relating to the purchase of the right to use immovable properties on a timeshare basis (OJ 1994 L 280/83); Art. 14 of the Directive 97/7/EC of the European Parliament and of the Council of 20 May 1997 on the protection of consumers in respect of distance contracts (OJ 1997 L 144/19); Art. 8(2) of the Directive 1999/44/EC of the European Parliament and of the Council of 25 May 1999 on certain aspects of the sale of consumer goods and associated guarantees (OJ 1999 L 171/12).

67) See Directive 2002/65/EC of the European Parliament and of the Council of 23 September 2002 concerning the distance marketing of consumer financial services and amending Council Directive 90/619/ EEC and Directives 97/7/EC and 98/27/EC (OJ 2002 L 271/16); see Reich [27], p. 171.

${ }^{68)}$ See Heiss [17], p. 32 et seq; Weber-Rey [37], p. 220; European Commission, Green Paper on Financial Services Policy, COM (2005) 177 final; EESC, CESE 1626/2004, para. 6.3.1.
} 
insurance contract comprehensively. ${ }^{69}$ This is not to say that a partial or minimum standard regulation would not help at all. It simply would not be sufficient to achieve the completion of the internal insurance market, which is, after all, what should be aspired.

\subsubsection{Optional Instrument and Mandatory Insurance Contract Law}

In order to achieve its aims, an optional instrument must not only allow parties to opt out of non-mandatory but also out of mandatory rules of national insurance contract law. ${ }^{70}$ The choice must be freed from any restrictions imposed by current private international law. It follows that the optional instrument must provide appropriate mandatory rules of insurance contract law, effectively substituting the protection of the policyholder under national law. It is particularly important that the European legislator applies a high level of protection in the optional instrument, just as it must do with other community acts according to Art. 95(3) EC Treaty. ${ }^{71}$

It may appear contradictory to ask for an optional instrument which would only be applicable if parties opt in favour of it and at the same time to request a comprehensive regulation of mandatory rules on insurance contract law in such an optional instrument. ${ }^{72}$ However, the apparent contradiction disappears when the option of the parties is restricted to choosing the instrument as a whole or not at all. ${ }^{73}$ A national system with a high degree of protection for the policyholder would thereby be replaced by a European system offering a different kind of protection, yet at just as high a level. ${ }^{74}$ Since a partial choice would be excluded, the insurers would not be allowed to pick and choose parts of each system to their own benefit.

\subsection{The PEICL as an Optional Instrument}

It has been demonstrated that the PEICL have not only been drafted as a Common Frame of Reference of European Insurance Contract Law but also as an optional instrument. ${ }^{75}$ The option granted in Art. 1:102 of the PEICL complies with all the requirements which have been discussed above. Therefore, the PEICL also serve as a model optional instrument for the European legislator.

\section{References}

1. Basedow, J.: Der Gemeinsame Referenzrahmen und das Versicherungsvertragsrecht. ZEuP 280 (2007)

2. Basedow, J.: Der Versicherungsbinnenmarkt und ein optionales europäisches Vertragsgesetz. In: Wandt et al. (ed.): FS Egon Lorenz 93 (2004)

3. Basedow, J.: Die Gesetzgebung zum Versicherungsvertrag zwischen europäischer Integration und Verbraucherpolitik. In: Reichert-Facilides, Schnyder (eds.): Versicherungsrecht in Europa - Kernperspektiven am Ende des 20. Jahrhunderts. ZSR Beiheft 34, 13 (2000)

\footnotetext{
${ }^{69)}$ Basedow [2], p. 104.

${ }^{70)}$ See with regard to mandatory law in general Martiny [25], p. 215 et seq.

71) See EESC, CESE 1626/2004, para. 6.2.

72) As to mandatory rules in optional contract law in general, see Heiss/Downes [19], p. 697 and 699.

73) Basedow [2], p. 105; Heiss/Downes [19], p. 709 et seq.

74) Heiss/Downes [19], p. 699.

${ }^{75)}$ See supra 3.2.8.
} 
4. Basedow, J.: Ein optionales Europäisches Vertragsgesetz - Opt-in, Opt-out, wozu überhaupt? ZEuP 1 (2000)

5. Basedow, J.: Insurance Contract Law as Part of an Optional European Contract Act. LMCLQ 500 (2003)

6. Bayerische Rück: Primary insurance market Central and Eastern Europe - Overview (2000)

7. Blaurock, U.: Lex mercatoria und Common Frame of Reference. ZEuP 118 (2007)

8. Brödermann, E.: Betrachtungen zur Arbeit am Common Frame of Reference aus der Sicht eines Stakeholders: Der weite Weg zu einem europäischen Vertragsrecht. ZEuP 304 (2007)

9. Clarke, M.: The Law of Insurance Contract (2006)

10. Clarke, M., Heiss, H.: Towards a European Insurance Contract Law? Recent Developments in Brussels, Journal of Business Law (JBL) 600 (2006)

11. Flessner, A.: Der Gemeinsame Referenzrahmen im Verhältnis zu anderen Regelwerken. ZEuP 112 (2007)

12. Grundmann, S., Kerber, W.: European System of Contract Law - A Map for Combining the Advantages of Centralised and Decentralised Rule-making. In: Grundmann, Stuyck (eds.): An Academic Green Paper on European Contract Law, p. 295 (2002)

13. Heiss, H.: Europäischer Versicherungsvertrag. VersR 1 (2005)

14. Heiss, H.: European Insurance Contract Law: Restatement - Common Frame of Reference - Optional Instrument. IJVO (Internationale Juristenvereinigung Osnabrück) 13, 1 (2006)

15. Heiss, H.: Mobilität und Versicherung. VersR 448 (2006)

16. Heiss, H.: Principles of European Insurance Contract Law. In: Hendrikse, Rinkes (eds.): Insurance and Europe 41-59 (2007)

17. Heiss, H.: Stand und Perspektiven der Harmonisierung des Versicherungsvertragsrechts in der EG (2005)

18. Heiss, H. (ed.): An Internal Insurance Market in an Enlarged European Union (2002)

19. Heiss, H., Downes, N.: Non-Optional Elements in an Optional European Contract Law. Reflections from a Private International Law Perspective. ERPL 693 (2005)

20. Heiss, H., Schnyder, A.K.: Versicherungsvertrag. In: Kronke, Schnyder, Melis (eds.): Handbuch Internationales Wirtschaftsrecht, p. 195 (2005)

21. Lando, O.: Optional or Mandatory Europeanisation of Contract Law. ERPL 59 (2002)

22. Lando, O., Beale, H. (eds.): Principles of European Contract Law, Parts I and II (2000)

23. Lando, O., Clive, E., Prüm, A., Zimmermann, R. (eds.): Principles of European Contract Law, Part III (2003)

24. Looschelders, D.: Internationales Privatrecht - Art. 3 - 46 EGBGB (2004)

25. Martiny, D.: CFR und internationales Vertragsrecht. ZEuP 212 (2007)

26. Münchener Rück: Die mittel-osteuropäischen Versicherungsmärkte auf dem Weg zur EU (2000)

27. Reich, N.: Der Common Frame of Reference und Sonderprivatrechte im "Europäischen Vertragsrecht". ZEuP 161 (2007)

28. Reichert-Facilides, F.: Europäisches Versicherungsvertragsrecht. In: Basedow, Hopt, Kötz (eds.): FS Ulrich Drobnig 119 (1998)

29. Reichert-Facilides, F.: Gesetzgebung in Versicherungsvertragsrechtssachen: Stand und Ausblick. In: Reichert-Facilides, Schnyder (eds.): Versicherungsrecht in Europa - Kernperspektiven am Ende des 20. Jahrhunderts. ZSR Beiheft 34, 1 (2000)

30. Reithmann, C., Martiny, D.: Internationales Vertragsrecht (2004)

31. Schlechtriem, P.: Internationales UN-Kaufrecht (2005)

32. Schnyder, A. K.: Parteiautonomie im europäischen Versicherungskollisionsrecht. In: Reichert-Facilides (ed.): Aspekte des internationalen Versicherungsvertragsrechts im Europäischen Wirtschaftsraum, p. 49 (1994)

33. Schulze, R.: Gemeinsamer Referenzrahmen und acquis communautaire. ZEuP 130 (2007)

34. Staudenmayer, D.: Ein optionelles Instrument im Europäischen Vertragsrecht? ZEuP 828 (2003)

35. Trstenjak, V.: Die Auslegung privatrechtlicher Richtlinien durch den EuGH: Ein Rechtsprechungsbericht unter Berücksichtigung des Common Frame of Reference. ZEuP 145 (2007)

36. Wandt, M.: Internationales Privatrecht der Versicherungsverträge. In: Reichert-Facilides, Schnyder (eds.): Versicherungsrecht in Europa - Kernperspektiven am Ende des 20. Jahrhunderts. ZSR Beiheft 34,85 (2000)

37. Weber-Rey, D.: Harmonisation of European Insurance Contract Law, in: Vogenauer/Weatherill (eds.), The harmonisation of European contract law: implications for European private laws, business and legal practice (2006), 207 